\title{
An unexpected aromatization reaction during the preparation of 1,2-cyclohexanedione ethers
}

\author{
Ryan DeAngelis, Amy Solinski and David A. Hunt \\ Department of Chemistry, The College of New Jersey, 2000 Pennington Road, \\ Ewing, NJ 08628, USA
}

(Received August 8, 2016; Revised October 31, 2016; Accepted November 1, 2016)

\begin{abstract}
In a heretofore-unreported reaction, 1,2-cyclohexandione reacts with a variety of alcohols under mild acid-catalyzed dehydration conditions to afford not only ethers of 1,2- cyclohexanedione but the corresponding aryl ethers as well in moderate to good yield.
\end{abstract}

Keywords: 1,2-cyclohexanedione; aromatization; aryl ethers. (C) 2017 ACG Publications. All rights reserved.

\section{Introduction}

During the course of a synthetic methods investigation, we required the preparation of the diosphenol ether 3 from the reaction of o-bromobenzyl alcohol (1) and 1,2-cyclohexanedione (2) in accordance to a literature procedure (Scheme 1). ${ }^{1}$ While the desired product was observed, much to our surprise we isolated the corresponding phenyl ether $\mathbf{4}$ in significant, albeit low yield. This prompted us to investigate the reaction of a variety of alcohols with 1,2-cyclohexanedione under acidic conditions.<smiles>OCc1ccccc1Br</smiles><smiles>O=C1CCCCC1=O</smiles>
2<smiles>Cc1ccccc1</smiles>

$\mathrm{D}$<smiles>O=C1CCCC=C1OCc1ccccc1Br</smiles>

3a<smiles>Brc1ccccc1COc1ccccc1</smiles>

$4 a$

Scheme 1. Acid-catalyzed reaction of o-bromobenzyl alcohol with 1,2-cyclohexanedione

\footnotetext{
*Corresponding author: E-Mail: hunt@tcnj.edu
} 


\section{Experimental Section}

\subsection{Chemicals}

1,2-Cyclohexanedione was purchased from Ontario Chemicals and was used as received. Other chemicals were purchased from Sigma-Aldrich Chemicals. IR spectra were recorded on a Perkin-Elmer Spectrum Two Fourier Transform Infrared Spectrometers. ${ }^{1} \mathrm{H}(400 \mathrm{MHz})$ and ${ }^{13} \mathrm{C}(100$ MHz) NMR were recorded on a Bruker Biospin Ascend $400 \mathrm{MHz}$ Nuclear Magnetic Resonance Spectrometer using $\mathrm{CDCl}_{3}$ as solvent and TMS as an internal standard. Silica gel flash column chromatography was performed using E. Merck silica gel (230-400) and E. Merck TLC plates. Low resoultion mass spectrometry was performed on a Agilent 6890 Gas Chromatograph/5973 Quadrapole Mass Spectrometer System at $70 \mathrm{eV}$ with a 7683B Autoinjector. The high-resolution mass spectrum was obtained on an Agilent LCTOF.

2.2 General method for the preparation of aryl ethers: Compounds $\mathbf{4 a - d}$ and $\mathbf{4 g - \mathbf { j }}$ were synthesized by the method detailed below and their structural assignment confirmed by comparison of spectral data to that reported in the literature.

Preparation of 1,2-dimethoxy-4-(2-phenoxyethyl)benzene (4e): To a $250 \mathrm{~mL}$ round bottom flask equipped with a Dean-Stark tube and reflux condenser was added 1,2-cyclohexanedione $(1.12 \mathrm{~g} ; 10 \mathrm{mmol})$ dissolved in toluene $(100 \mathrm{~mL}) . \quad 3,4$ Dimethoxy- $\beta$-phenylethyl alcohol $(2.28 \mathrm{~g} ; 12.5 \mathrm{mmol})$ was then added to the flask, followed by the addition of $p$-TSA (170 mg; $0.98 \mathrm{mmol}$ ). The reaction mixture was refluxed for $24 \mathrm{~h}$. The reaction was cooled to $0^{\circ} \mathrm{C}$, and an additional $125 \mathrm{~mL}$ of toluene was added. The mixture washed with $100 \mathrm{~mL}$ of $0.5 \mathrm{M}$ $\mathrm{Na}_{2} \mathrm{CO}_{3}$. The organic layer was separated and washed with additional $0.5 \mathrm{M} \mathrm{Na}_{2} \mathrm{CO}_{3}(2 \times 200$ $\mathrm{mL})$. The organics were then dried $\left(\mathrm{MgSO}_{4}\right)$, filtered and concentrated in vacuo, The crude product was purified by column chromatography on silica gel eluting with 98:2 hexanes/EtOAc to afford a $4 \mathbf{e}$ as clear colorless viscous oil: $(697 \mathrm{mg} ; 27 \%)$ : ${ }^{1} \mathrm{H}$ NMR (400 $\left.\mathrm{MHz}, \mathrm{CDCl}_{3}\right)$ 87.27-7.15 (m, 7H), 6.90-6.82 (m, 3H), $3.90(\mathrm{~s}, 3 \mathrm{H}), 3.92(\mathrm{~s}, 3 \mathrm{H}), 4.20(\mathrm{t}, J=$ $7.2 \mathrm{~Hz}, 2 \mathrm{H}), 3.08(\mathrm{t}, J=7.2 \mathrm{~Hz}, 2 \mathrm{H}) ;{ }^{13} \mathrm{C}$ NMR $\left(100 \mathrm{MHz}, \mathrm{CDCl}_{3}\right)(100 \mathrm{MHz}$, $\left.\mathrm{CDCl}_{3}\right) \delta 158.8,149.1,147.7,131.1,129.5,120.9,120.8,114.6,112.5,111.4,68.9,56.0,55$ .9, 35.6. HRMS for $\mathrm{C}_{16} \mathrm{H}_{18} \mathrm{O}_{3}$ : calc'd $m / z$ : 258.1256; found $m / z: 258.1261$.

\section{Results and Discussion}

Using a variety of aryl substituted alcohols, we found that in each case a substantial amount of aryl ether product along with the expected dione ether was formed and in several cases, the aryl ethers were the major product (1e, 1g-1i). We found this interesting in light of the work of Kablaoui who has described the aromatization of 1,2-, 1,3-, and 1,4-cyclohexanediones using forcing conditions employing a strong acid/ $\mathrm{Ac}_{2} \mathrm{O} / \mathrm{AcOH}$ system (Scheme 2) to afford pyrocatechol, resorcinol, and hydroquinone after hydrolysis of he corresponding O-acylated derivatives, ${ }^{2}$ while Feigenbaum, et. al. have described the conversion of 3-aryl-1,2-cyclohexanediones to the corresponding catechols using a p-toluenesulfonyl chloride/ $\mathrm{K}_{2} \mathrm{CO}_{3} / \mathrm{AIBN}$ system (Scheme 3 ). ${ }^{3}$

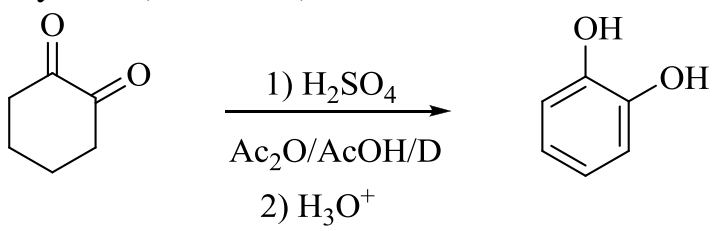

2

Scheme 2. Aromatization of 1,2-cyclohexanedione to catechol under acidic conditions 
These reaction conditions are far more rigorous compared to those employed in this study. ${ }^{4} \mathrm{~A}$ possible mechanism for aryl ether formation is shown below (Scheme 4).<smiles>[R][X]1ccc(C2=C(O)C(=O)CCC2)cc1[R]</smiles>

$$
\frac{\mathrm{P}-\mathrm{TsCl}}{\mathrm{K}_{2} \mathrm{CO}_{3} / \mathrm{AIBN}}
$$<smiles>[R][X]1ccc(C2=C(O)C(=O)CCC2)cc1[R]</smiles>

6

Scheme 3. Aromatization of 1,2-cyclohexanedione derivatives to catechol under basic conditions<smiles>[R]OC1=CCCCC1=O</smiles>

3

4

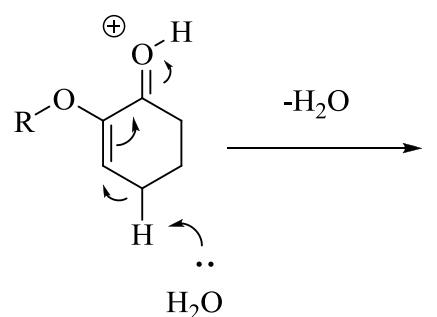

7<smiles>[R]OCC1C=CC([Hg]C=O)C=C1</smiles>

11<smiles>[R]OC1=C(O)C(CC)CC=C1</smiles><smiles>[R]OC1C=CCCC1O</smiles>

8 9

10

Scheme 4. Proposed mechanism for the aromatization of ethers derived from 1,2-cyclohexandione under acidic conditions

\section{Conclusion}

1,2-Cyclohexanedione can undergo dehydrative aromatization reactions with alcohols under relatively mild conditions. To the best of our knowledge, this type of mild aromatization reaction with 1,2-cyclohexanedione has not been reported. Future studies will focus on the scope and limitations of this chemistry. 
Table 1. Synthesized Compounds

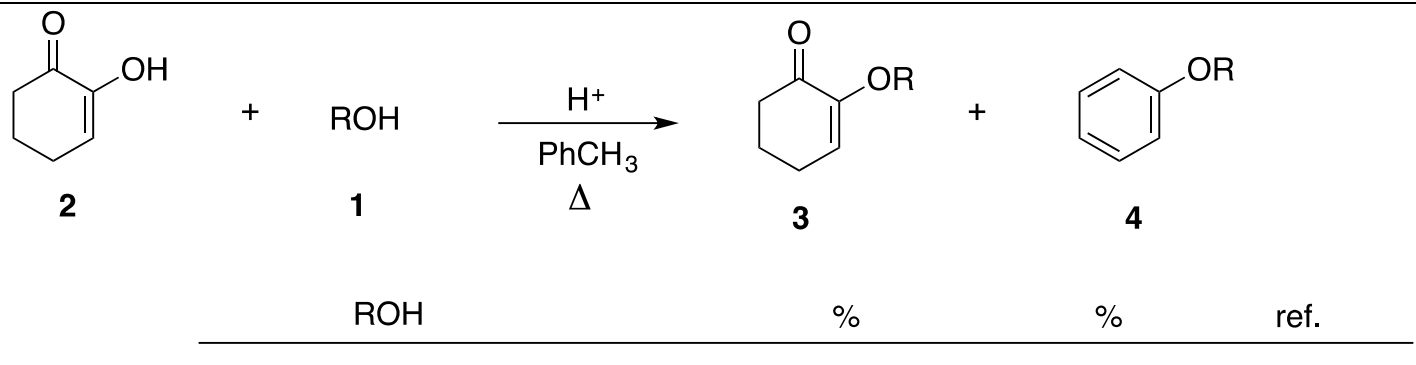

(b)

${ }^{a}$ based on stoichiometry of 1 mole hydroquinone/1 mole 1,2-cyclohexanedione. The ether product is 4-phenoxy-phenol
b based on stoichiometry of 1 mole diol/2 moles 1,2 -cyclohexanediol

\section{Acknowledgements}

We wish to thank The College of New Jersey for their generous support of this work. 


\section{Supporting Information}

Supporting Information accompanies this paper on http://www.acgpubs.org/OC

\section{References}

[1] Svennebring, A.; Nilsson, P.; Larhed, M. Microwave-accelerated spiro-cyclizations of o-halobenzyl cyclohexenyl ethers by palladium (0) catalysis. J. Org. Chem. 2007, 72, 5851-5854.

[2] Kablaoui, M.S. J. Aromatization of cyclic ketones II. Novel synthesis of substituted dihydroxybenzenes J. Org. Chem. 1974, 39, 3696-3698.

[3] Feigenbaum, A.; Pete, P.P.; Poquet-Dhimane, A. A new aromatization of 1,2-cyclohexanedione. Easy synthesis of 3-arylcatechols. Tetrahedron Lett. 1989, 29, 73-74.

[4] Wu, W-B.; Huang, J-M. Electrochemical cleavage of aryl ethers promoted by sodium borohydride. $J$. Org. Chem. 2014, 79. 10189-1015.

[5] Cano, R.; Perez, J.M.; Ramon, D.J.; McGlacken, G.P. Imprgnated palladium on magnetite as catalyst for direct arylation of heterocycles. Tetrahedron 2016, 72, 1043-1050.

[6] Campeau, L-C.; Parisien, M.; Leblanc, M.; Fagnou, K. Biaryl synthesis via direct arylation: establishment of an efficient catalyst for intramolecular processes. J. Am. Chem. Soc. 2004, 126, 91869187.

[7] Ohta, A. Simple preparation of some aryl ethers. Synthesis 1982, 828-829.

[8] Barton, D.H.R.; Finet, J.P.; Motherwell, W.B.; Pichon, C. The chemistry of pentavalent organobismuth reagents. Part 8. Phenylation and oxidation of alcohols by tetraphenylbismuth esters. J. Chem. Soc. Perkin Trans. 1, 1987, 251-259.

[9] Shintou, T.; Mukaiyama, T. Efficient Methods for the Preparation of Alkyl-Aryl and symmetrical or unsymmetrical dialkyl ethers between alcohols and phenols or two alcohols by oxidation-reduction condensation. J. Am. Chem. Soc. 2004, 126, 7359-7367.

[10] Simon, M-O.; Girard, S.A.; Li, C-J. Catalytic aerobic synthesis of aromatic ethers from non-aromatic precursors. Angew. Chem, Int. Ed. 2012, 51, 7337-7540.

[11] Bauer, G.; Cheung, C.W.; Hu, X. Cross-coupling of nonactivated primary and secondary alkyl halides with aryl Grignard reagents catalyzed by chiral iron pincer complexes. Synthesis 2015, 47, 1726-1732.

[12] Evindar, G.; Deng, H.; Morgan, B. Preparation of amino acid derivatives as modulators of sphingosine1-phosphate (S1P1) receptor activity. U.S. Patent Appl. 20060223866, October 5, 2006.

[13] v. Braun, J. Synthesis of compounds of the phenylpropane, phenylbutane and phenylpentane series. Berichte der Deutschen Chemischen Gesellschaft 1911, 43, 2837-2852.

[14] Marcune, B.F.; Hiller, M.C.; Marcoux, J-F.; Humphrey, G.R. Selective displacement of aryl fluorides with hydroquinone: synthesis of 4- phenoxyphenols. Tetrahedron Lett. 2005, 46, 7823-7286.

[15] Zhang, Q. Tian, M.; Han, Y.; Wu, C.; Li, Z.; Wang, Y. Synthesis, aggregation behavior and interfacial activity of branched alkylbenzenesulfonate gemini surfactants. J. Colloid Interface Sci. 2011, 362, 406414.

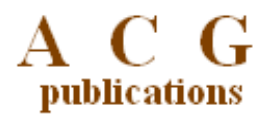

(C) 2017 ACG Publications 